\section{Re: Barn i Norge som ikke har rett til behandling - finnes de?}

I sin kommentar under medisinsk etikk-spalten i Tidsskriftet nr. 5/2016 (1) refererer Svein Aarseth til vår artikkel i samme nummer (2). Han skriver: «Barnet var født med analatresi. Det ble anlagt stomi, og man så for seg endelig kirurgisk behandling med tilbakelegging av stomien. Imidlertid endret sykehuset sin behandlingsplan fordi barnet skulle sendes ut av landet». Vi ønsker å påpeke at i vår artikkel står det klart at barnets søknad om asyl, og dermed hans asylsøknad, ikke ble endelig klargjort av Utlendingsnemda (UNE) før flere måneder senere. Barnekirurgens egen oppfatning er det Svein Aarseth uttrykker, og det er i strid med familiens faktiske status dokumentert i brevet til sykehuset, hvor UNE ber om en oppdatering av barnets medisinske behandling. I UNEs brev begjæres det en helsemessig oppdatering i forbindelse med klagebehandlingen, samtidig som det står at iverksettelsen av vedtaket for resten av familien er utsatt. Barnekirurgisk avdeling svarte da at barnet kunne leve helt bra resten av livet med utlagt tarm. På grunnlag av denne medisinske vurderingen avslo UNE familiens ankesøknad. Dette er det vi er kritiske til når det gjelder barnekirurgens behandling av barnet. Vi ser at dette allerede er kommentert både faglig og etisk av lederne for barnemedisinsk forening, Ketil Størdal og Ingebjørg Fagerli (i kommentaren på Tidsskriftets nettside.)

Mons Lie
mons.lie@online.no
Patji Alnæs-Katjaviv

Mons Lie (f. 1938) er dr.med. og spesialist i karkirurgi og i thoraxkirurgi. Ingen oppgitte interessekonflikter.

Patji Alnæs-Katjavivi (f. 1973) er spesialist i gynekologi og ph.d.-stipendiat ved Oslo universitetssykehus.

Ingen oppgitte interessekonflikter.

\section{Litteratur}

1. Aarseth S. Barn i Norge som ikke har rett til behandling - finnes de? Tidsskr Nor Legeforen 2016; 136: 447.

2. Alnæs-Katjavivi P. Lie M. Barnet på det innvandringspolitiske alter? Tidsskr Nor Legeforen 2016; 136: 387-8.

\section{Re: Skredulykker og behandling av skredtatte}

I sin artikkel om skredulykker og behandling av skredtatte i Tidsskriftet nr. 5/2016 (1) omtaler Skaiaa og Thomassen dødsårsakene hos de omkomne og fremhever hypoksi/ufrie luftveier, traumer og hypotermi som de viktigste. Fremstillingen kan nyanseres noe av erfaringene fra skredulykken i Vassdalen i 1986.

Skredet i Vassdalen var et tørt flakskred av fast fokksnø uten snøblokker, isblokker eller stein i skredmassene og uten store trær i området (2). Tretti soldater ble tatt av raset, og 16 av dem omkom. Av disse ble 10 obdusert ved Regionsykehuset i Tromsø.

En av de omkomne hadde fraktur av tre ribben og hemothorax. For øvrig var obduksjonsfunnene påfallende like og uten andre mekaniske skader enn tegn til generell kompresjon av kroppen. De aller fleste hadde et markert avtrykk i huden av tekstilene $\mathrm{i}$ undertøyet over hele kroppen. Alle hadde en hard, maksimalt kontrahert venstre ventrikkel, lungeødem, hjerneødem og petecchiale blødninger i serøse og mukøse membraner. De fleste hadde et isskjold foran nese og munn. Ikke hos noen av de omkomne ble det observert luftlomme foran nese og munn.

Vi oppfattet avtrykket av undertøyet som uttrykk for et massivt press fra snømassene som hadde gjort inspirasjonsbevegelser umulig, presset vevsvæske over i blodbanene og blodet mot de to områdene som var beskyttet av omgivende skjelett, hjernen og thoraxhulen. I thorax ville vevstrykket holde seg lavt ved at luften i lungene ville unnvike. Fraværet av luftlomme og funnet av isskjold tett inntil nese og munn bekreftet at ingen effektiv respirasjon hadde funnet sted. Den maksimalt kontraherte venstre ventrikkel ble oppfattet som ischemisk kontraktur. For redningsarbeidet innebærer det at utvendig hjertemassasje vil ha liten eller ingen effekt. Ikke hos noen av de skredtatte i Vassdalen førte forsøkene på resuscitering til spontan hjerte- eller respirasjonsaktivitet. Blodgassanalyser av blod fra aortabuen fra ni av ofrene indikerte at hos fem hadde blodsirkulasjonene stoppet før oksygentrykket hadde rukket å bli kritisk lavt, mens fire døde av akutt respirasjonssvikt.

Vår konklusjon var at observasjonene passet med kompresjon av thorax og kroppen forøvrig som medførte forhindrete respirasjonsbevegelser og alvorlige sirkulasjonsforstyrrelser med sannsynlig raskt bevissthetstap og påfølgende sirkulasjonsstans i løpet av få minutter hos noen, og etter at oksygentrykket hadde falt til fatalt nivå hos andre.

\section{Helge Stalsberg \\ hstalsb@online.no}

Helge Stalsberg (f. 1932) er er professor og tidligere overlege ved Avdeling for klinisk patologi ved Universitetssykehuset i Troms $\varnothing$.

Ingen oppgitte interessekonflikter

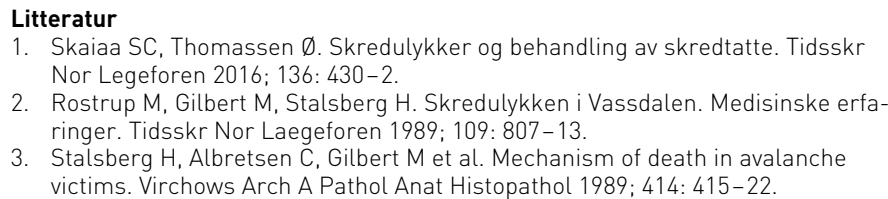

\section{Re: Er det trygt å føde hjemme?}

Det er min erfaring at antallet hjemmefødsler har økt noe i løpet av de siste årene. Det kan være ulike årsaker til dette. Mediedekninger av hjemmefødsler blant enkelte kjendiser kan kanskje hatt en betydning, kanskje også den fokusen på et enklere liv nærmere naturen i enkelte grupper. Henvisning til Nederland hvor hjemmefødsler utgjør en betydelig andel av alle fødsler, er ikke relevant for Norge. På dette området er organiseringen av fødselsomsorgen og nærhet til sykehus med fødselsberedskap helt forskjellig.

Det er derfor på sin plass at Tidsskriftet i nr. 6/2016 refererer den ferske studien fra USA som entydig viser at planlagt hjemmefødsel var assosiert med høyere perinatal dødsrate og høyere odds for indusert fødsel, instrumentell forløsning og keisersnitt, i tillegg til lav apgarskår og kramper hos barnet $(1,2)$.

Jeg har i mange år diskutert denne problemstillingen med mine amerikanske kolleger, og fått det klare inntrykk at dette lenge har vært en vanlig oppfatning. Å føde heter på amerikansk «to deliver» (å levere, direkte oversatt). En av kollegene uttrykte sitt syn ganske klart på følgende måte: «Home deliveries? - pizzas only!». Når jeg tidligere diskuterte denne problemstillingen med studentene, syntes det som om denne enkle formuleringen ble klart forstått - det vil den antagelig også bli av mødre som vurderer hjemmefødsel.

\section{Dag Bratlid}

bratlid@vikenfiber.no

Dag Bratlid er tidligere professor ved Norges teknisk-naturvitenskapelige universitet og tidligere overlege i nyfødtmedisin ved Barne- og ungdomsklinikken ved St. Olavs Hospital.

Ingen oppgitte interessekonflikter.

\section{Litteratur}

1. Rostadmo M. Er det trygt å føde hjemme? Tidsskr Nor Legeforen 2016; 136: 530.

2. Snowden JM, Tilden EL, Snyder J et al. Planned out-of-hospital birth and birth outcomes. N Engl J Med 2015; 373: 2642-53. 